\title{
GENDER MESSAGES IN CONTEMPORARY POPULAR MALAY SONGS
}

\author{
Collin Jerome \\ Centre for Language Studies, Universiti Malaysia Sarawak \\ jcollin@cls.unimas.my
}

\begin{abstract}
Gender has been an important area of research in the field of popular music studies. Numerous scholars have found that contemporary popular music functions as a locus of diverse constructions and expressions of gender. While most studies focus on content analyses of popular music, there is still a need for more research on audience's perception of popular music's messages. This study examined adult Malay listeners' perceptions of gender messages in contemporary Malay songs. A total of 16 contemporary Malay songs were analysed using Fairclough's (1992) method of text analysis. The content of the songs that conveyed messages about gender were the basis for analysis. The results showed that the messages revolve mainly around socially constructed gender roles and expectations in romantic relationships. Gender stereotypes are also used in the songs to reinforce men's and women's roles in romantic relationships. The results also showed that, while listeners acknowledge the songs' messages about gender, their own perceptions of gender and what it means to be a gendered being in today's world are neither represented nor discussed fully in the songs analysed. It is hoped the findings from this, particularly the mismatch between projected and perceived notions of gender, contribute to the field of popular Malay music studies in particular, and popular music studies in general where gender messages in popular songs and their influence on listeners' perceptions of their own gender is concerned.
\end{abstract}

Keywords: gender, Malay, popular Malay songs, romantic relationship

\section{Introduction}

Gender has been an important area of research in the field of popular music studies. Numerous scholars have argued that popular music functions as a locus of diverse constructions and articulations of gender. This is clearly evidenced in the way popular music conveys powerful ideas and messages about gender which continues to shape people's perceptions of their own gender. Walser (1993), for instance, posits that music and lyric help construct people's gender identities in a compelling way by "infusing them with power and implying that they are natural and desirable" (p. xvi). Furthermore, popular music has long been regarded as being loaded with 
traditional gender roles and stereotypes. Rock music in the West, for example, is rich with stereotypical gender behaviours where men are visibly and commonly portrayed as "sexually aggressive, rational, demanding and adventuresome" and women as "emotional, deceitful, illogical, frivolous, dependent, and passive" beings (Berns, 2010, p. 484). Studies have shown that popular music not only serves as a site of construction, but also a subversion of gender role-stereotypes. Western rock music in particular intermittently disputes dominant gender and sex roles by allowing the interaction between traditional masculinity, femininity, androgyny, and homosexuality in the process of masculine identity construction (Mäkelä, 2004). Studies have also shown that popular music is traditionally linked to its central and most enduring theme: romance and love (Ostlund \& Kinnier, 1997 as cited in Bader, 2007). Holtzman (2000), for instance, maintains that "popular music has traditionally featured romance as its central theme with lyrics sung by both men and women, proclaiming the joy of love and the agony of its loss" (pp. 88-89). These lyrics are packed with dominant ideas and messages about gender, particularly gender role expectations and stereotypes in romantic relationship which include men as the "pursuer and most interested in sex" and women as the "pursued and most interested in romance" (Hotlzman, 2000, p. 88). It would certainly be interesting to find out how the lyrics of popular music convey ideas and messages about gender and the various ways listeners respond to them and reflect on their own gender in the process.

\section{Purpose of the study}

This study examined adult Malay listeners' perceptions of gender messages in contemporary popular Malay songs. It begins by analysing messages about gender in the-lyrics, followed by an analysis of adult Malay listeners' perceptions of these messages as well as their own ideas about gender and what it means to be a gendered being in today's modern world.

\section{Methodology}

Twelve adult Malay female respondents, aged 23-33, were selected using purposeful sampling method (see Patton, 1990). The respondents were attached to Universiti Malaysia Sarawak (UNIMAS) when the study was conducted. They were all welleducated (having received tertiary education ranging from diploma to master's degree level) and were regular listeners of contemporary popular Malay songs. The songs analysed for this study were chosen based the respondents' favourite popular Malay songs they regularly listen to on the radio (see Table 1). This method of song selection is based on Hakaman and Well's (1993) technique of gathering listeners' favourite songs for lyrical analysis in popular music studies.

There were two main procedures involved in the study: the analysis of the song lyrics and focus group interviews. The song lyrics were analysed using Fairclough's (1992) method of examining the words (especially word meaning and 
wording) and metaphors used in lyrics. Fairclough (1992) posits that metaphors encompass other figures of speech including simile and personification, all of which influence people's thinking, behaviour, knowledge, and beliefs in a powerful way (as cited in Locke, 2004). Copies of the song lyrics were distributed to the respondents prior to the focus group interviews. Almost all respondents knew the song lyrics by heart which eased the interviewing process.

Table 1

Selected popular Malay songs

\begin{tabular}{lll}
\hline Song title & Singer(s) & Gender \\
\hline 1. Kian & Asmawi Ani @ Mawi & Male \\
2. Sembunyi & Misha Omar featuring Andy Flop & Female \\
& Poppy & \\
3. Dewi & Dewa 19 & Male \\
4. Aku Cinta Kau dan Dia & Ahmad Dhani/Dewa 19 & Male \\
5. Sandaran Hati & Letto & Male \\
6. Cahaya Cinta & Siti Nurhaliza & Female \\
7. Lagu Jiwa Lagu Cinta & Mawi featuring M. Nasir & Male \\
8. Sesuatu Janji & Taufik Batishah & Male \\
9. Biarlah Rahsia & Siti Nurhaliza & Female \\
10. Aku Bukan Untuk Mu & Rossa@ Sri Rossa Roslaina Handiyani & Female \\
11. Terlalu Cinta & Rossa @ Sri Rossa Roslaina Handiyani & Female \\
12. Izinkan Aku Pergi & Kaer@ Wan Mohammad Khair Wan & Male \\
& Azami & \\
13. Terlalu Istimewa & Adibah Noor & Female \\
14. Mungkir Bahagia & Hazami @ Nor Kamal Hazami Ahmad & Male \\
15. Jikalau Aku & Ezlyn @Azline Ariffin & Female \\
16. I'm Sorry Goodbye* & Kris Dayanti & Female \\
\hline
\end{tabular}

*The lyric as shown in Appendix 1 is written in Malay, with an exception of the title and the final lines of the chorus which are both written in English.

The interviews were carried out in six sessions, each involving two respondents. This was purposely done given that the respondents were made up of six pairs of close friends/colleagues who spent most of their time together during and after office hours. The pairing allowed the respondents to feel at ease when discussing gender messages in the songs. During the interview, the respondents were asked to comment on messages about gender in the song lyrics and the extent to which these messages were consistent with their own perceptions of gender and what it meant to be a gendered being in today's world. Each interview session lasted nearly an hour and the feedbacks and comments were audiotaped, and then transcribed verbatim. 


\section{Results and Discussion}

The results from the lyrical analysis showed that contemporary popular Malay songs, particularly those analysed in the study, focused on heterosexual romantic relationship except for the song "Sandaran Hati" that revolved around spiritual love and the song "Terlalu Istimewa" that centred on love for the dearly departed. The results corroborate Holtzman's (2000) and Paxson's (2003) observations that romance and romantic relationships are the central feature of many of popular songs today. The results also showed that the songs conveyed messages about gender role expectations and stereotypes in romantic relationships, namely, leaving one's lover and concealing one's feelings and desires for the other. The lyrical analysis further revealed that physical-anatomical, natural and abstract objects were used to convey and reinforce these messages.

\section{Leaving one's lover}

Most of the songs analysed conveyed dominant gender role expectations in romantic relationships where men were depicted as more inclined to leave their lovers while women endured the pain as a consequence. The word pergi (go or take leave) was frequently used to describe men's decision to leave their female lovers as evidenced in the songs sung by male singers. Women, on the hand, blamed themselves for the breakups, in addition to being portrayed as emotional, as evidenced in the use of the word menyesal (regret) in the songs sung by female singers. The analysis of the song lyrics also revealed gender role stereotypes in a love triangle. For example, women were portrayed as the ones who still pined for their former lovers despite having forged new relationships as illustrated in the song "Terlalu Cinta":
Jangan dekat atau jangan datang kepadaku lagi
Aku semakin tersiksa karena tak memilikimu
Kucoba jalani hari dengan pengganti dirimu
Tapi hatiku selalu berpihak lagi padamu
Do not come near or come back to me again
I'm getting more hurt for not having you
I try to move on with a new lover
But my heart still pines for you

Men, on the other hand, were depicted as opportunists in a love triangle. For example, they could easily break their promises and choose one woman, and leave the other as evidenced in the songs "Aku Cinta Kau dan Dia" and "Mungkir Bahagia". Men were also depicted as having the ability (and even the liberty) to leave their lovers with a promise that they would return to them after settling some unfinished business as shown in the song "Suatu Janji". At least one song, "I'm sorry goodbye" challenged dominant gender role expectations in romantic relationship, 
where women were portrayed as the one who could leave and even abandon the relationship:

\author{
maafkan ku harus pergi \\ ku tak suka dengan ini \\ aku tak bodoh \\ seperti kekasihmu yang lain \\ I'm sorry I have to go \\ I do not like this \\ I'm not stupid \\ like your other lovers
}

"Terlalu Istimewa" was also another exception. The act of leaving centred more on the demise of a loved one, most probably a child rather than a lover's decision to leave or abandon a romantic relationship.

\title{
Concealing one's feelings
}

Most of the songs analysed represented men as being less expressive of their feelings in a romantic relationship. Sadness, loneliness and pain were only felt and contained from within as illustrated through the use of words such as pilu di dalam dada (sadness of/in the heart), tak nampak di mata (the eyes cannot see), and batin terseksa (tormented heart) in the song "Kian". Such feelings reinforce the dominant view that men are not allowed to show lapse of emotional control or express signs of emotional vulnerability in romantic relationships (see Seidler, 2006). Men's feelings and desires for women as presented in the song "Lagu Cinta Lagu Rindu" had to be repressed for fear of public exposure. Such feelings could only be expressed through singing (menyanyi) and dancing (menari). This amplifies the Adler and Proctor's (2010) contention that "men often express their feelings through actions and activities rather than in words" (p. 129).

However, the lyrical analyses revealed that men were not the only ones who concealed their feelings. In the song "Biarlah Rahsia," the female singer persuaded her listeners (women in particular) to put themselves in her shoes by understanding what she was going through in her relationship as she was determined to keep the bond with her lover a secret: ku putuskan, biarlah rahsia (I've decided keep it a secret). The song "Sembunyi" revealed another level of emotional concealment, unlike male singers whose suppressed feelings were expressed through singing and dancing, the female singer concealed her feelings for her lover or love interest through body language and gestures, namely, eye contact (e.g., bertentang mata) and facial expressions (e.g., bibirku bisu). The irony is that these supposedly concealed feelings were not only acknowledged by her lover or love interest, but were also noticed by others (e.g., Tersentap lalu ku sedar di perhatikan). 


\title{
The use of physical-anatomical, natural and abstract objects as metaphors
}

The lyrical analysis showed that physical-anatomical objects such as hati, dada, and jiwa (heart) as well as mata (eyes) and bibir (lips) were used in the songs as metaphors for feelings and emotions in romantic relationships. For instance, the heart was used by male singers to represent the place where love dwelt and it was in this place that feelings were concealed and disclosed as evidenced in the song "Kian" (e.g., sebak di dada, pilu di dalam dada). Natural and abstract objects were also used as metaphors to convey and reinforce dominant messages about gender in romantic relationship. For example, in the song "Mungkir Bahagia", malam (night) and ombak (waves) represented the male singer's feelings of loneliness and sadness.

\author{
Gerimis duka \\ Malamku kelam \\ Ombak lara \\ Drizzle of sorrow \\ My night is dark \\ Waves of sadness
}

An interesting contrast was evidenced in the song "Sembunyi" where malam (night) was described as full of stars, signifying hope and passion for lovers (e.g., bintang-bintang di malam). Natural and even supernatural objects such as udara (air), nyanyian (songs) and dewi (goddess) were used in the song "Dewi" as metaphors to represent women and their beauty in romantic relationships while tugu (statue) was used in the song "Cahaya Cinta" to metaphorically represent the male lover's ego and pride. There was an exception of using abstract subject such as God in some of the songs analysed. The female singer in the song "I'm sorry goodbye", for instance, sought God's blessings and assistance, and thanked Him for revealing the truths about the man's infidelity and unfaithfulness. The male singer in the song "Sandaran Hati", on the hand, sought God's guidance in both love and life.

It can be concluded that contemporary popular Malay songs, especially those analysed in this study, convey messages about the dominant gender role expectations and stereotypes in romantic relationships which include men leaving or abandoning their lovers and concealing their feelings and desires for their lovers. These messages are further shaped by the demands of culture and tradition as projected most clearly in the song "Jikalau Aku," where men should seek their female lovers' parental consent (izin) and blessings (restu).

\section{Focus group interviews}

The results from focus group interviews indicated that all respondents acknowledged the dominant gender messages in the songs analysed. When asked about the songs' messages about men's and women's role expectations and stereotypes, the respondents agreed that women were lyrically depicted as being emotionally dependent and vulnerable in romantic relationships, despite the 
evidence of female emotional strength in the songs "Terlalu Cinta" and "I'm Sorry Goodbye." This corresponds with Bern's (2010) view of popular music's portrayal of women as "emotional," "dependent," and "passive" beings (p. 484). The respondents also agreed that men were expected to exert power and authority in the relationship (e.g., initiating communication) and women were supposed to repress their feelings and desires for the opposite sex. One respondent cited the Sunnah to indicate that Malay Muslim men were expected to play more dominant roles while Malay Muslim women were expected to play more submissive roles and be bound by tradition, culture and religion no matter how "educated" and "openminded" they had become. Such a response corresponds with numerous scholars' view that the concept of Malay Muslim subjectivity within the context of the Malay world is deeply influenced and molded by culture and religion (see Khoo, 2006; Ong \& Peletz, 1995; Ruzy 2006). Ruzy Suliza Hashim (2006), for instance, maintains that Malay Muslim men are expected to become fathers and the heads of the households, while Malay Muslim women are expected to comply with and actualise their fitrah (human natural disposition) by becoming wives and mothers (p. 16). The respondents claimed that they had no qualms with the use of physical-anatomical, natural and abstract objects in the song lyrics to represent women mainly because these objects were commonly used in songs sung by male singers to praise women and show their love for them. The respondents also pointed out that there were many popular Malay songs sung by male singers who addressed their lovers by name such as the songs "Isabella" and "Juwita". However, the respondents admitted that it would be rather uncommon and even unwomanly for female singers to call their lovers by name. The use of pronouns such as mu (you) and dia (him) as evidenced in the song "Terlalu Cinta" was more socially acceptable.

However, to show contrast with the earlier views that somehow accept the norms of how men and women are lyrically represented, the respondents argued that dominant messages about women in the songs analysed, in particular, and popular Malay songs, in general, must be redressed and corrected. This amplifies Shuker's (2003) view on resistance, where popular music listeners "work with the form itself [i.e. song or song lyric], break it up and subvert its conventions" (p. 55; notes added). One respondent pointed out that women continued to be portrayed in popular Malay songs as victims of men's infidelity and her immediate reference to the song "Papa Jahat" which was not analysed in the study justified her claim. The song, as the respondent recalled, showed men's tendency to be unfaithful and sexually promiscuous in the husband-wife relationship. Other respondents claimed that popular Malay songs should emulate the West where western female singers were more liberated in challenging normative gender roles. The respondents cited Juliana Banos, a Malay female singer whose songs were not analysed in the study, to show that women could also play more dominant roles in romantic relationship. In Juliana's song "Mana Satu," for instance, the woman took takes on the role as the pursuer, rather than the pursued, and the one who has the liberty to choose the right lover or partner for herself. This challenges the dominant gender roles in romantic love songs where men are often portrayed as "the pursuer" while women are "the pursued" (Holtzman, 2000, p. 88). Since the songs analysed mostly revolved around romantic relationship, the respondents argued that ideas and messages 
about what it meant to be a woman in today's modern world were neither represented nor discussed fully in the lyrics. What seemed to be lacking, as the respondents claimed, was the image of the modern Malay woman and the many roles she plays: a career woman, a wife, a mother, a daughter and so on. Popular Malay songs, as the respondents argued further, should portray the modern Malay woman who has the same rights as men and who displays and possesses a "modern" outlook and mannerism (i.e. superior, intelligent, dependable) which are key to overcoming the challenges and demands of today's world.

\section{Conclusion}

It can be concluded that contemporary popular Malay songs, particularly those analysed in this study, not only transmit prevailing messages about gender role expectations and stereotypes in romantic relationships, but fail to represent fully listeners' perceptions of their gender and the roles they take on or assume in these relationships. This is because such songs, as the respondents claim, are primarily created for entertainment purposes or for listening pleasures only. They believe that lagu puisi (poetic song) is the most appropriate and effective medium to convey diverse ideas and messages about gender. While the respondents agree with the songs' portrayal of female roles in romantic relationship, they argue that the songs' messages about women must be redressed and corrected. This corroborates Shuker's (2001) view that dominant ideas, messages, and meanings produced in popular music are infinite rather than finite as they are constantly mediated and resisted by listeners. It is not wrong to say that popular Malay songs, in particular, and popular music, in general, can serve as important sites of construction and subversion where dominant ideas about gender are not only conveyed, constructed, and reinforced, but also subverted and redefined by listeners' diverse ideas about gender.

It should be mentioned that the findings of this study were drawn from a small sample of adult Malay women and their views about their gender and gender messages in the songs may not be representative of the views of Malay women in Malaysia and beyond. Despite the fact that the study was conducted in 2007, many popular Malay songs in Malaysia today continue to convey normative gender role expectations and stereotypes. It is also important to mention that analysing popular songs using Fairclough's (1992) method of textual analysis can be quite subjective, particularly when the analysis is influenced by the researcher's own understanding and personal biases. Future research on popular Malay songs (or songs of other ethnicity) may consider using other more systematic methods of analysing gender messages in the song lyrics and listeners' perceptions of these messages. Such methods include content analysis of song lyrics (see Wimmer \& Dominick, 2011) and audience analysis (see Longhurst 2007). Holtzman's (2000), for instance, outlines a set of questions to help researchers elicit listeners' opinions (and their own in the process) of gender roles in popular songs that feature romantic love relationship: 
[I]s there an indication of whether men or women are the aggressors, the most romantic, and the most sexual? What does this small sample tell you about roles of men and women in popular music? To what degree are the relationships featured intense, dramatic, romantic, conversational? What messages are conveyed about the nature of romantic relationships?. . .To what extend did your sample reinforce or challenge the dominant ideology of the gender roles in romantic relationships and the nature of the relationships itself? Are the relationships in this sample similar or different to the relationships you have had? (pp. 88-89)

The following questions can also be addressed in future work on gender in popular Malay songs:

- How are men and women represented in recent popular Malay songs?

- How do the lyricists of popular Malay songs represent masculinity and femininity?

- What do the song lyrics tell us about the lyricists' choice of words in portraying men and women? What do these words tell us about the lyricists' own notions of masculinity and femininity?

- Are these notions shaped by dominant ideas of gender?

- How might a study on lyricists' representations and listeners' perceptions help expose diverse views about gender within the Malay society?

It is hoped the findings from these future research will contribute to the field of popular Malay music studies in particular, and popular music studies in general where gender messages in popular songs and their influence on listeners' perceptions of their own gender is concerned.

\section{References}

Adler, R. B., \& Proctor II, R. F. (Eds.). (2010). Looking out/looking in (13th ed.). Boston, MA: Wadsworth.

Bader, A. (2007). "Love will steer the stars" and other improbable feats: Myths in popular love songs. In M. Galician \& D. L. Merskin (Eds.), Critical thinking about sex, love, and romance in the mass media: Media literacy applications (pp. 141160). Mahwah, NJ: Lawrence Erlbaum Associates, Inc.

Berns, R. M. (2010). Child, family, school, community: Socialisation and support (8th ed.). Belmont, CA: Wadsworth.

Fairclough, N. (1992). Critical language awareness. London: Longman.

Hakaman, E. A., \& Wells, A. (1993). Music preference and taste cultures among adolescents. Popular Music and Society, 17(1), 55-69.

Holtzman, L. (2000). Media messages: What film, television, and popular music teach us about race, class, gender and sexual orientation. New York, NY: M. E. Sharpe, Inc.

Khoo, G. C. (2006). Reclaiming adat: Contemporary Malaysian film and literature. Vancouver, BC: UBC Press. 
Locke, T. (2004). Critical discourse analysis. London, UK. Continuum.

Mäkelä, J. (2004). John Lennon imagined: Cultural history of a rock star. New York, NY: Peter Lang Publishing.

Patton, M. Q. (1990). Qualitative research and evaluative methods (3rd ed.) Sage Publications: Thousand Oaks, CA.

Paxson, P. (2003). Media literacy: Thinking critically about music \& media. Portland, ME: J. Weston Walch Publisher

Longhurst, B. (2007). Popular music and society (2nd ed.). Cambridge, UK: Polity Press.

Ong, A., \& Peletz, M. (Eds.). (1995). Bewitching women, pious men: Gender and body politics in Southeast Asia. Berkeley, CA: University of California Press.

Ruzy Suliza Hashim. (2006). Meniti duri dan ranjau: pembikinan gender dan seksualiti dalam konteks dunia Melayu [Scaling mines and thorns: the construction of gender and sexuality in the context of the Malay world]. Sari: International Journal of Malay World Studies, 24, 15-34.

Seidler, V. J. (2006). Transforming masculinities: Men, cultures, bodies, sex and love. Oxon, UK: Routledge.

Shuker, R. (2001) Understanding popular music (2nd ed.). Oxon, UK: Routledge.

Walser, R. (1993). Running with the devil: Power, gender, and madness in heavy metal music. Middleton, $\mathrm{CT}$, Wesleyan University Press.

Wimmer, R. D., \& Dominick, J. R. (2011). Mass media research: An introduction (9th ed.). Boston, MA: Wadsworth.

\section{Appendix}

\section{I'm Sorry Goodbye}

Sebelum bertemu denganmu

Diriku bahagia

Semenjak bertemu denganmu

Ku makin bahagia

Semakin lama aku

Semakin tau tentang engkau

Sedikit kecewa

Ternyata engkau tak baik

Pertama tama semua manis

Yang engkau berikan

Membuat aku merasakan

Cinta sebenarnya

Semakin hari

Semakin terungkap

Yang sesungguhnya

Kumakin kecewa

Ternyata kau penuh dusta 
Maafkan ku harus pergi

Ku tak suka dengan ini

Aku tak bodoh

Seperti kekasihmu yang lain

Terima kasih oh Tuhan

Tunjukkan siapa dia

Maaf kita putus

So thank you so much

I'm sorry goodbye 